\title{
Creep Mechanisms of an Al-Cu-Mg Alloy at the Macro- and Micro-Scale: Effect of the S'/S Precipitate
}

\author{
Yongqian $\mathrm{Xu}{ }^{1,2,3}$, Lingwei Yang ${ }^{1,4}$, Lihua Zhan ${ }^{1,2,3, * \mathbb{D}}$, Hailiang $\mathrm{Yu}^{1,2}$ and Minghui Huang 1,2,3 \\ 1 State Key Laboratory of High-Performance Complex Manufacturing, Central South University, \\ Changsha 410083, China \\ 2 College of Mechanical and Electrical Engineering, Central South University, Changsha 410083, China \\ 3 Light Alloy Research Institute, Central South University, Changsha 410083, China \\ 4 China Aerodynamics Research and Development Center, Mianyang 621000, China \\ * Correspondence: yjs-cast@csu.edu.cn
}

Received: 20 July 2019; Accepted: 2 September 2019; Published: 9 September 2019

check for updates

\begin{abstract}
A novel methodology combining the macro- and micro-creep techniques was employed to study the effect of $\mathrm{S}^{\prime} / \mathrm{S}$ precipitate growth on the creep mechanism of an Al-Cu-Mg alloy. An AA2524 alloy was pre-aged at $180^{\circ} \mathrm{C}$ to obtain $\mathrm{S}^{\prime} / \mathrm{S}$ precipitates with various sizes. The results showed that the precipitate size increased approximately linearly to $\approx 32 \mathrm{~nm}, \approx 60 \mathrm{~nm}$, and $\approx 105 \mathrm{~nm}$ after $3 \mathrm{~h}$, $6 \mathrm{~h}$, and $12 \mathrm{~h}$ of pre-aging, respectively. The growth of precipitate could significantly shorten the primary creep stage, despite the fact that the steady-state creep behavior was similar to that of the as-received alloy, as revealed by the macro tensile creep tests at $180{ }^{\circ} \mathrm{C}$ and $180 \mathrm{MPa}$. This led to a stress exponent (2.4-2.5) of the $\mathrm{Al}$ alloy with various precipitate sizes that was quite close to that of the as-received $\mathrm{Al}$ alloy, implying a steady-state creep mechanism dominated by grain boundary sliding and dislocation interactions. Finally, the micro-creep tests showed a minor role of the precipitate size on the steady-state creep mechanism, as evidenced by the similar strain rate sensitivity $(0.0169-0.0186)$, activation volume $\left(\approx 27 \mathrm{~b}^{3}\right)$, and the results of a detailed transmission electron microscopy analysis of all tested alloys.
\end{abstract}

Keywords: creep age forming; creep behavior; precipitate; nano-indentation; $\mathrm{Al}-\mathrm{Cu}-\mathrm{Mg}$ alloy

\section{Introduction}

$\mathrm{Al}-\mathrm{Cu}-\mathrm{Mg}$ alloys (known as 2000 series) have been widely applied in aircraft components due to their low density and high damage tolerance [1-3]. Some complex aircraft components are generally manufactured by creep age forming (CAF), which is a new processing technique to simultaneously strengthen the $\mathrm{Al}-\mathrm{Cu}-\mathrm{Mg}$ alloys and change their shapes during a one-step forming and heat-treatment process [4-6]. In order to acquire aircraft components with high performance and high precision by CAF, it is vitally important to study fundamentally the creep aging mechanism of $\mathrm{Al}-\mathrm{Cu}-\mathrm{Mg}$ alloys. Macroscale creep tests have been widely employed to evaluate the creep properties of $\mathrm{Al}$ alloys by correlating the processing conditions (creep stress, temperature, and aging time) with the microstructures (precipitate, grain size, grain boundaries, etc.) and creep properties [7-12]. Zhan et al. [10] explored the microstructures and mechanical properties of creep-aged $\mathrm{Al}-\mathrm{Cu}-\mathrm{Mg}$ alloy sheets (AA2524) depending on creep temperature, aging time, and sheet thickness. Maximov et al. [11] quantified the effect of creep temperature on strain hardening and creep behavior of an $\mathrm{Al}-\mathrm{Cu}-\mathrm{Mg}$ alloy (2024-T3). Chen et al. [12] investigated the evolution of $\mathrm{S}^{\prime}$ precipitate in an $\mathrm{Al}-\mathrm{Cu}-\mathrm{Mg}$ alloy during stress-free and stress aging. They found that the precipitation distribution of the $\mathrm{S}^{\prime}$ phase during stress aging could be changed by the loading orientation of the applied stress. Moreover, compressive stress aging may lead to a shorter $S^{\prime}$ phase, and the length of the $S^{\prime}$ phase tends to decrease with the increase 
of the applied stress. However, the effect of the growth of $S^{\prime} / S$ precipitates on the creep mechanism has not been reported yet.

Since the macro-creep behavior of typical Al alloys generally combines contributions from multiscale factors, such as nanoscale precipitates, microscale grains, meso- and macroscale porosities, it is still challenging to decouple the effect of each microstructural feature and to rationalize the creep mechanism of typical $\mathrm{Al}-\mathrm{Cu}-\mathrm{Mg}$ alloys for $\mathrm{CAF}$ applications. In order to highlight the contribution of individual microstructures on the creep mechanism of a material, microscale creep techniques based on the indentation technique [13-16] have been developed recently, such as constant strain rate, constant load, indentation strain-rate jump techniques. Among them, the indentation strain-rate jump technique is advantageous to acquire rate-dependent strength during single tests and has been applied in multiple metal/alloy systems (nanograined $\mathrm{Ni}$, ultrafine-grained $\mathrm{Al}$, etc. [17-20]). However, this technique has not been extensively applied to $\mathrm{Al}-\mathrm{Cu}-\mathrm{Mg}$ alloys to study the basic creep mechanisms dominated by particular microstructures such as precipitates during CAF.

This study focuses on the investigation of the creep mechanism of an $\mathrm{Al}-\mathrm{Cu}-\mathrm{Mg}$ alloy, exploring the effect of precipitate size by a combined micro- and macro-creep technique. A typical AA2524 alloy was pre-aged at high temperature $\left(180^{\circ} \mathrm{C}\right)$ to obtain precipitates with tailored size. Transmission electron microscopy (TEM) was used to study the precipitate microstructures and to measure the precipitate sizes after various pre-aging times. The effect of the precipitate size on the primary and steady-state creep behaviors of the $\mathrm{Al}$ alloy was studied by macro-creep tests, and the dominated macro-creep mechanism was discussed. In order to clarify the role of the precipitate size on the creep mechanism at the microscale, indentation strain-rate jump tests were performed on the $\mathrm{Al}$ alloy with different precipitate sizes. The rate-dependent creep was discussed with the help of the measured strain rate sensitivity and activation volume of the $\mathrm{Al}$ alloy. The creep mechanism was finally verified by direct observations of the interactions of dislocations with the precipitates during micro-creeping by TEM.

\section{Material and Methods}

A commercial high-strength cold-rolled AA2524 alloy was used in this study. The as-received alloy has undergone $\mathrm{T} 3$ treatment, i.e., $1-2 \%$ pre-deformation at room temperature after solution treatment to eliminate quenching residual stress. Its chemical composition is presented in Table 1 . Prior to the creep tests, the as-received alloy was pre-aged for $3 \mathrm{~h}, 6 \mathrm{~h}$, and $12 \mathrm{~h}$ at $180{ }^{\circ} \mathrm{C}$, in order to obtain precipitates with different microstructures. An optical microscope Olympus IX71 (Olympus, Tokyo, Japan) was employed to characterize the grain structures of the $\mathrm{Al}$ alloy after pre-aging processing. In addition, TEM (Tecnai-F20, FEI, Hillsboro, OR, USA) was employed to study the evolution of the precipitate with pre-aging time. To achieve this, TEM lamellae were fabricated by electro-polishing of a mechanically thinned disc ( $3 \mathrm{~mm}$ in diameter and 60-80 $\mu \mathrm{m}$ in thickness). After polishing, the total thicknesses of all TEM lamellae were $<100 \mathrm{~nm}$, and nanoscale precipitates could be characterized.

Table 1. Chemical composition of the AA2524 alloy (wt\%).

\begin{tabular}{ccccccccc}
\hline Zn & Mg & Cu & Mn & Si & Fe & Ti & Cr & Al \\
\hline 0.01 & 1.38 & 4.4 & 0.66 & 0.03 & 0.05 & 0.03 & 0.01 & Bal. \\
\hline
\end{tabular}

\subsection{Macro-Creep Tests}

A constant stress tensile creep technique was applied to quantify the macro-creep behavior of the Al alloy on a SUST-D5 creep testing machine (SUST, Zhuhai, China) with an assisting furnace. The creep specimen with gauge length of $50 \mathrm{~mm}$ was machined by wire-electrode cutting along the rolling direction of the AA2524 alloy sheet [3]. The detailed dimensions of the creep specimen are shown in Figure 1. The creep temperature was $180^{\circ} \mathrm{C}$ to obtain an $\mathrm{Al}$ alloy with high strength and fine precipitates. In order to measure the temperature of the specimen precisely, three thermocouples (K-type; Ni/Al-Ni/Cr) were tied on the top, middle, and bottom of the specimen. The creep stress was $180 \mathrm{MPa}$, and the creep time was $12 \mathrm{~h}$. During the creep tests, the creep load was applied after the 
temperature of the specimen reached a steady value of $180{ }^{\circ} \mathrm{C}$ at a heating rate of $5{ }^{\circ} \mathrm{C} / \mathrm{min}$. At the end of the tests, the applied loading was released, and the specimen was naturally cooled down to room temperature outside the furnace. Uniaxial tensile tests were also performed at macroscales using an SUST-CMT5105 machine (SUST, Zhuhai, China) at room temperature with a strain rate of $0.033 \mathrm{~mm} / \mathrm{s}$. Each experiment was repeated for at least three times.

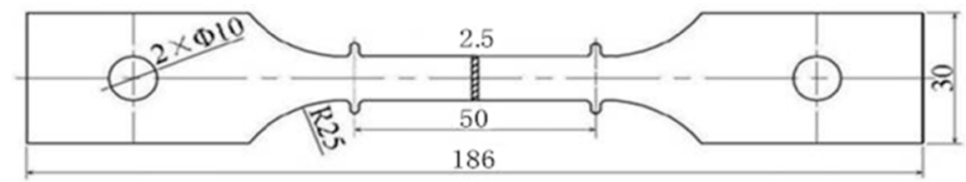

Figure 1. Geometry and dimensions of the creep specimen (unit: $\mathrm{mm}$ ).

\subsection{Micro-Creep Tests}

A novel indentation strain-rate jump technique was employed to study the creep behavior of the $\mathrm{Al}$ alloy at the microscale, following the Maier's method [17,21]. Prior to the test, the Al alloy was wire-cut $\left(8 \times 8 \mathrm{~mm}^{2}\right)$ and finely polished by diamond particles $(<1 \mu \mathrm{m})$ to eliminate the artificial residual stress. The indentation test was implemented in an Agilent G200 nanomechanical system (Keysight, Santa Rosa, CA, USA) with a Berkovich diamond indenter. A continuous stiffness method (CSM) was used to insert the indenter on the finely polished sample to a fixed depth, e.g., $2500 \mathrm{~nm}$ in this work, and then unload to recover the elastic deformation. The shallow penetration depth can impose a stress field that is mainly confined in the grain closest to the indenter, thus the measured indentation is strongly localized. The CSM method is advantageous to acquire the hardness of an alloy continuously, based on the measured indentation force-depth curve, as typically shown in Figure 2a,b. At a shallow indentation depth $(<100 \mathrm{~nm})$, the measured hardness was unrealistically high (up to $6 \mathrm{GPa}$ ) due to the indentation size effect (ISE). The ISE arises when intense plastic deformation is forced to occur across a very small volume of an initially defect-free crystalline material. As the indenter penetrated deeper, the size effect was weakened, and when the depth surpassed $1500 \mathrm{~nm}$, the hardness stabilized and was almost independent of the indentation depth. A strain-rate jump sequence was thus set at this indentation depth regime, jumping from $0.005 / \mathrm{s}$, to $0.05 / \mathrm{s}$, and to $0.005 / \mathrm{s}$ every $250 \mathrm{~nm}$, as depicted in Figure 2a. Each rate jump correlated with a hardness value that was dependent on it (Figure 2b). Thus, the indentation strain-rate jump test is highly efficient to obtain the strength (hardness) of a material at different strain rates during a single indentation test. Since indentation is sensitive to the thermal drift caused by temperature gradients between the diamond indenter and the testing $\mathrm{Al}$ alloy, prior to each indentation test, the instrumental stability was assured by bringing the indenter in contact with the specimen surface with a small load $(2 \mu \mathrm{N})$ and allowing over an hour to reach equilibrium. This method enables a drift rate $<0.01 \mathrm{~nm} / \mathrm{s}$. In order to acquire reliable indentation results, at least 15 indentation tests were performed, and in each test the indentation was separated by at least $25 \mu \mathrm{m}$ (several times larger than the average indent width) from that of the previous test. More than two repetitive tests were conducted per condition. After the tests, several TEM lamellaes were extracted directly from the imprint cross sections of the $\mathrm{Al}$ alloys by the focused ion beam (FIB) technique in a Helios Nanolab G3 UC FIB/SEM dual-beam system (FEI, Hillsboro, OR, USA) for further characterizations. 

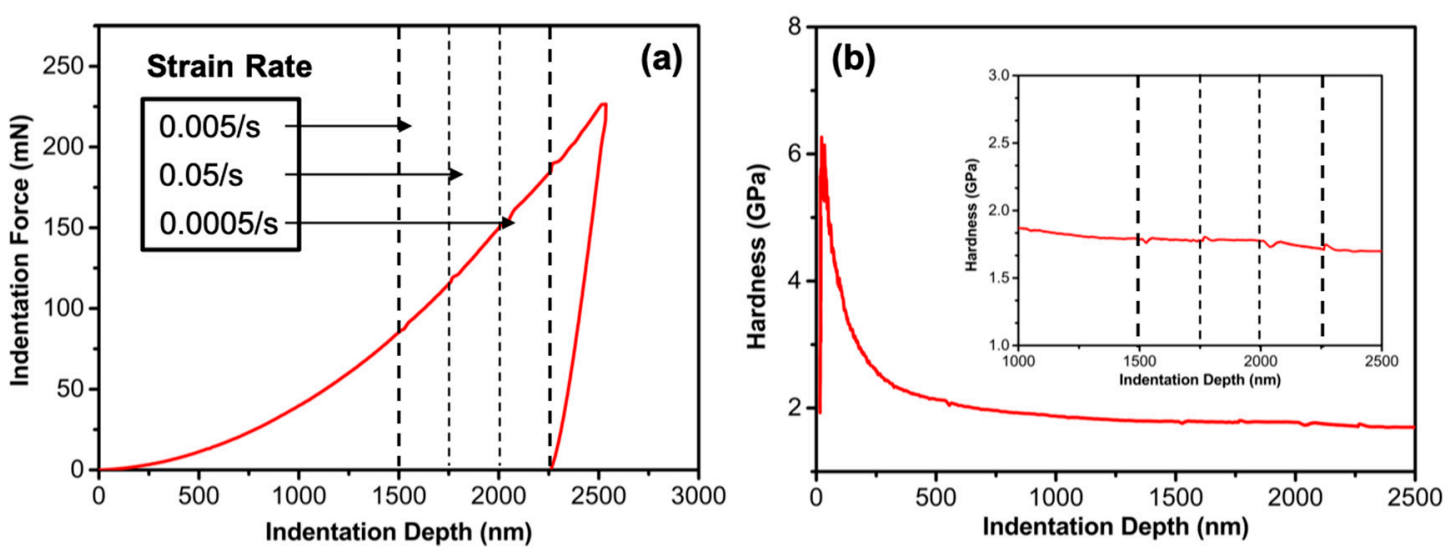

Figure 2. (a) Representative indentation force-depth curve of a strain-rate jump test. (b) Measured hardness versus indentation depth curve. The insert is a magnified figure of the strain-rate jump regime. The changes in the hardness are highlighted.

\section{Results and Discussion}

\subsection{Microstructure of the Pre-Aged Al Alloy}

Figure $3 \mathrm{a}, \mathrm{b}$ represent the grain structures of the as-received $\mathrm{Al}$ alloy and that after $12 \mathrm{~h}$ pre-aging. In addition, grain size statistics was carried out using the Image-Pro software(v6.0, Media Cybernetics, Washington, WA, USA). More than 2000 grains were measured for the $0 \mathrm{~h}$ and $12 \mathrm{~h}$ pre-aged AA2524. The grains in the as-received $\mathrm{Al}$ alloy were equiaxed, and the average grain size was $\approx 52 \mu \mathrm{m}$. The grain structure and size $(\approx 50 \mu \mathrm{m})$ were not evidently altered after $12 \mathrm{~h}$ pre-aging, evidencing a negligible effect of the pre-aging time. This was expected, since the aging temperature $\left(180^{\circ} \mathrm{C}\right)$ was much lower than the recrystallization temperature of the $\mathrm{Al}$ alloy $\left(300^{\circ} \mathrm{C}\right)[22]$.
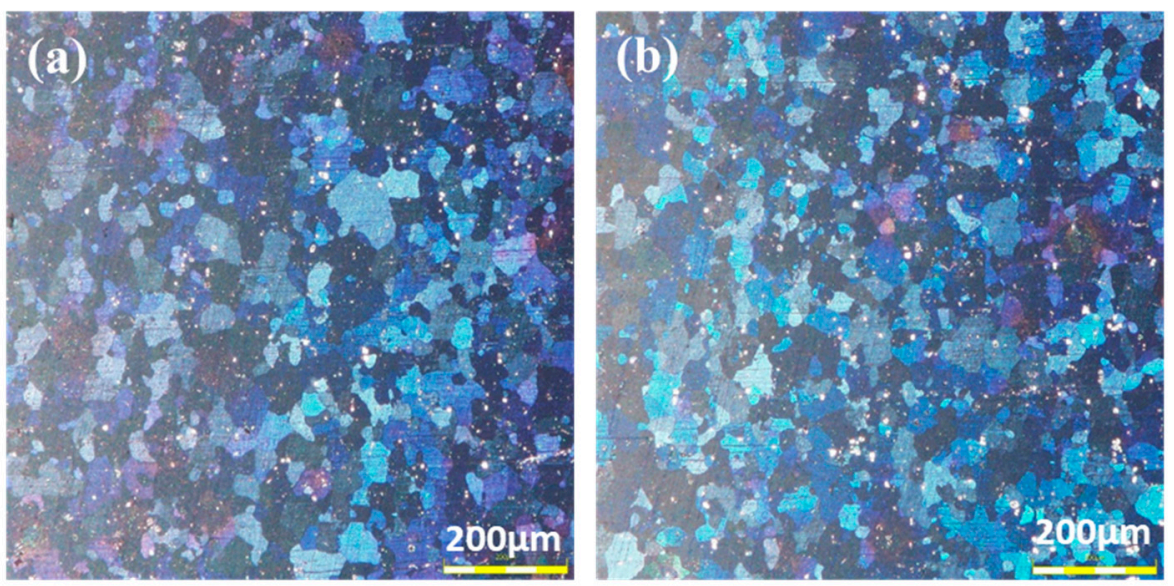

Figure 3. Optical micrograph illustrating the similar equiaxed grain structure of (a) $0 \mathrm{~h}$ and (b) $12 \mathrm{~h}$ pre-aged AA2524 alloy.

Figure 4 shows the precipitate microstructures of the $\mathrm{Al}$ alloy as a function of pre-aging time. The as-received alloy had a low dislocation density and was free of aging precipitate in individual grains. This is a typical microstructure of commercial AA2524 alloys. Note that pre-existing dislocations can be sources of creep deformation and nucleation sites of aging precipitates [23]. After pre-aging for $3 \mathrm{~h}$ at $180^{\circ} \mathrm{C}$, the microstructure was altered by the formation of a large amount of nano-sized precipitate, as shown in Figure $4 \mathrm{~b}$. The AA2x 24 series alloys are strengthened by the formation of this rod-shaped precipitate during ageing. The precipitation sequence for the ageing of $\mathrm{Al}-\mathrm{Cu}-\mathrm{Mg}$ alloys is: $\mathrm{SSS} \rightarrow \mathrm{GPB} / \mathrm{S}^{\prime \prime} \rightarrow \mathrm{S}^{\prime} \rightarrow \mathrm{S}[24,25]$. The optimum aging temperature range of AA2524 is $180-190{ }^{\circ} \mathrm{C}$, resulting in fine and uniformly distributed $\mathrm{S}^{\prime} / \mathrm{S}$ phases. As it can be seen from Figure $4 \mathrm{~b}$, 
these precipitates were nucleated and grew near the pre-existing dislocations, corresponding to the $S^{\prime} / S$ phase, and in the form of laths with the $\{120\}_{\mathrm{Al}}$ habit planes elongated along the $\langle 100\rangle_{\mathrm{Al}}$ direction $[12,26]$. They were distributed randomly and uniformly in the Al matrices, without obvious pre-orientation effects. The average size of the precipitate was $\approx 32 \mathrm{~nm}$. As the pre-aging time increased to $6 \mathrm{~h}$ and $12 \mathrm{~h}$, the size of the precipitate constantly increased to $\approx 60 \mathrm{~nm}$ and $\approx 105 \mathrm{~nm}$, as shown in Figure $4 \mathrm{c}, \mathrm{d})$.
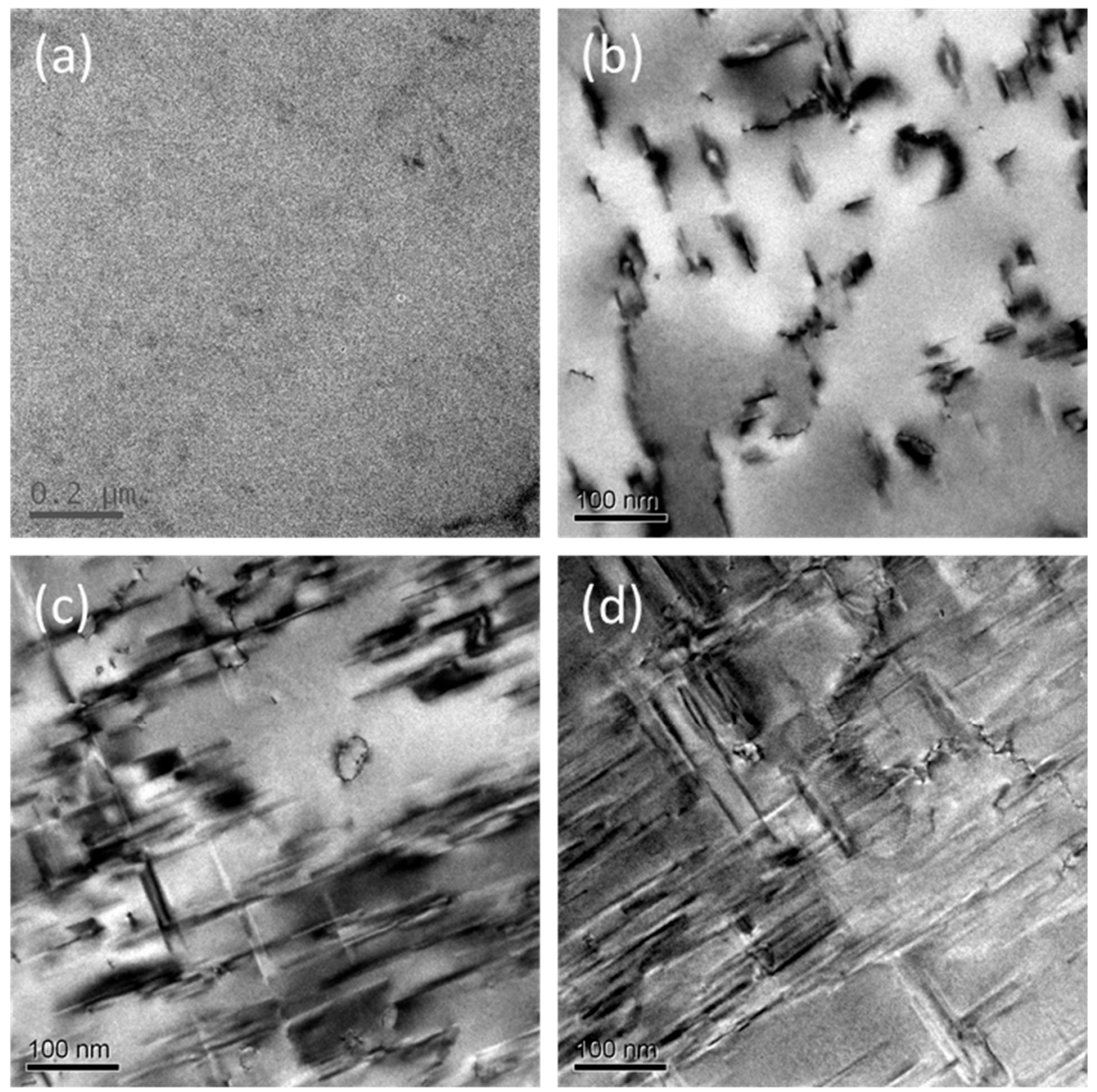

Figure 4. TEM images of intragranular microstructures of the pre-aged AA2524 alloy. (a) As-received material; (b) $3 \mathrm{~h}$ pre-aged; (c) $6 \mathrm{~h}$ pre-aged, and (d) $12 \mathrm{~h}$ pre-aged at $180^{\circ} \mathrm{C}$.

\subsection{Macro-Creep Mechanism}

The growth of the aging precipitates can have a strong effect on the tensile and creep properties of an $\mathrm{Al}$ alloy. Figure 5a shows the representative tensile stress-strain curves of the Al alloy as a function of the pre-aging time, showing higher yield strength and tensile strength (max. stress) for longer pre-aging times. The strengthening effect was expected due to the precipitation hardening of the larger precipitate that effectively prohibited dislocation activities. Note such strengthening would lead to degraded fatigue and toughness properties, as indicated by the declined elongation of the $\mathrm{Al}$ alloy for longer aging times. This is reasonable, since for typical $\mathrm{Al}$ alloys, their strengthening is generally achieved by sacrificing their toughness properties. Table 2 summarizes the tensile property evolution of the $\mathrm{Al}$ alloy. It is worthy pointing out that the growth of the aging precipitates can further restrict the creep behavior of the $\mathrm{Al}$ alloy, as shown in Figure 3b. After creeping for $12 \mathrm{~h}$ at $180 \mathrm{MPa}$ and $180^{\circ} \mathrm{C}$, the ultimate creep strain decreased from $0.179 \%$ for the as-received $\mathrm{Al}$ alloy to $0.119 \%$ after $12 \mathrm{~h}$ pre-aging. The decrease of the ultimate creep strain was mainly a consequence of the shortened primary creep stage of the $\mathrm{Al}$ alloy for longer pre-aging times. This can be explained by two possible mechanisms: (1) enhanced pinning effect of the dislocation motion by larger precipitates, 
and (2) decreased vacancies occupied by larger precipitates, which obstructed effectively the atomic diffusion. Following the primary creep, a steady creep stage occurred where the creep rates of the four $\mathrm{Al}$ alloys were quite close, i.e., $1.9 \times 10^{-6} / \mathrm{s}$, suggesting that the precipitate size had no effect on the steady creep behavior of the $\mathrm{Al}$ alloy.
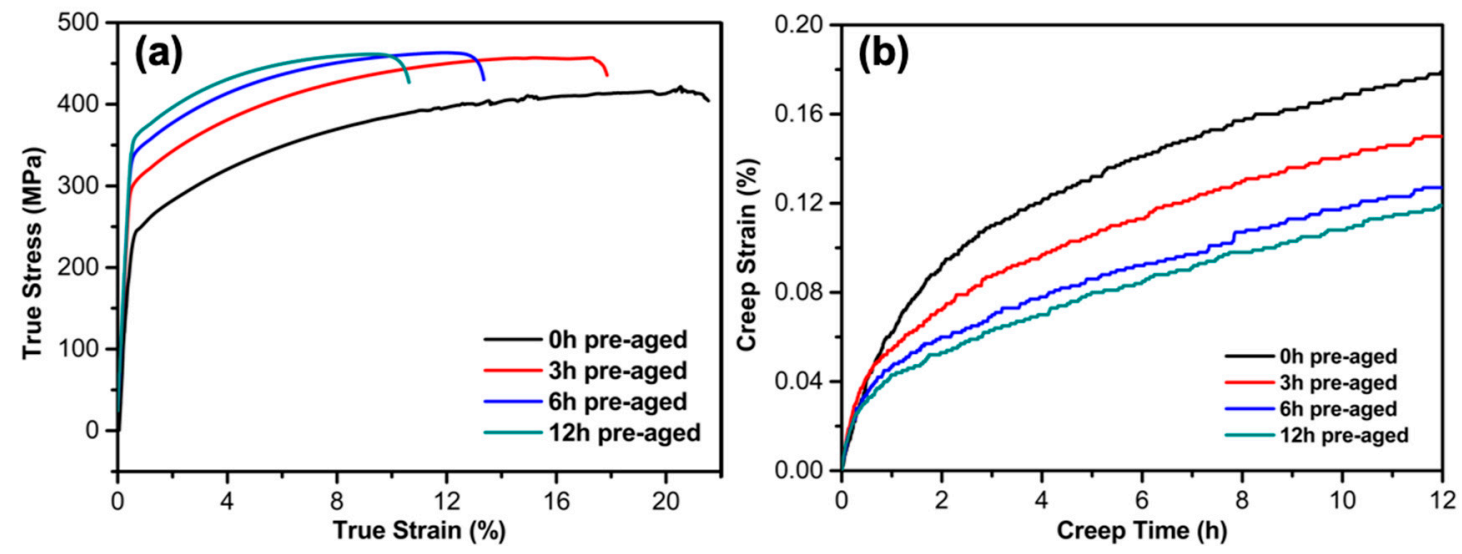

Figure 5. (a) Tensile stress-strain curves of the $\mathrm{Al}$ alloy as a function of pre-aging time; (b) creep strain-time curves of the alloy as a function of pre-aging time (elastic strain was removed).

Table 2. Mechanical properties of the initial material with various pre-aging treatments.

\begin{tabular}{cccccc}
\hline Pre-Aging & $\begin{array}{c}\text { Yield } \\
\text { Strength/MPa }\end{array}$ & $\begin{array}{c}\text { Tensile } \\
\text { Strength/MPa }\end{array}$ & Elongation/\% & $\begin{array}{c}\text { Ultimate } \\
\text { Creep Strain }\end{array}$ & $\begin{array}{c}\text { Steady } \\
\text { State Creep } \\
\text { Rate (s-1) }\end{array}$ \\
\hline $0 \mathrm{~h}$ & 265 & 403 & 22.18 & 0.00179 & $1.98 \times 10^{-6}$ \\
$3 \mathrm{~h}$ & 291 & 435 & 17.85 & 0.0015 & $1.91 \times 10^{-6}$ \\
$6 \mathrm{~h}$ & 303 & 440 & 13.64 & 0.00127 & $1.97 \times 10^{-6}$ \\
$12 \mathrm{~h}$ & 331 & 439 & 10.28 & 0.00119 & $1.88 \times 10^{-6}$ \\
\hline
\end{tabular}

In order to explore the mechanism dominating the insensitivity of the steady-state creep of the $\mathrm{Al}$ alloy with different precipitate sizes, the stress component $(n)$ of the as-received $\mathrm{Al}$ alloy and after $12 \mathrm{~h}$ pre-aging was calculated. The stress exponent $[2,9]$ correlates with the steady-state creep rates $\left(\dot{\varepsilon}_{s S}\right)$ and the stress levels $(\sigma)$ according to

$$
n=\frac{\partial \ln \dot{\varepsilon}_{s S}}{\partial \ln \sigma}
$$

In order to calculate $n$, creep tests of the as-received alloy and after $12 \mathrm{~h}$ pre-aging were performed under $140 \mathrm{MPa}, 180 \mathrm{MPa}$, and $210 \mathrm{MPa}$ at $180^{\circ} \mathrm{C}$. Figure $6 \mathrm{a}, \mathrm{b}$ shows the representative creep strain versus creep time of the $\mathrm{Al}$ alloy at different stress levels. As expected, a higher creep strain was triggered at higher stress levels, and pre-aging of the $\mathrm{Al}$ alloy hindered effectively its creep response. The $\dot{\varepsilon}_{s s}$ was thus plotted as a function of $\sigma$ in logarithmic coordinates, as shown in Figure 7. Based on Equation (1), the stress exponent was calculated by linear fitting of the data. For the as-received $\mathrm{Al}$ alloy, $n=2.5 \pm 0.4$. After $12 \mathrm{~h}$ pre-aging, $n=2.41 \pm 0.6$. Considering the error tolerance with heavy $\mathrm{n}$-value overlap, the result suggests strongly that the $\mathrm{n}$ exponent is independent of the pre-aging treatments. It has been widely accepted that the value of the stress exponent can be used to indicate the deformation mechanism of steady-state creep at the macroscale [2,27]. When $n=1$, the creep deformation is mainly controlled by diffusion, which is called diffusion creep. Grain boundary sliding leads to a value of $n$ close to 2 . The value of $n=3-4$ is related to dislocation slip mechanism. Based on this, the creep deformations of the $\mathrm{Al}$ alloy and after pre-aging were mainly dominated by the combination of grain boundary sliding and dislocation slipping. It seems that the growth of precipitates after pre-aging did not alter the steady creep mechanism of the $\mathrm{Al}$ alloy, and this also agrees well with the creep response of $\mathrm{Al}$ alloys with various pre-aging time (Figure $5 \mathrm{~b}$ ). 

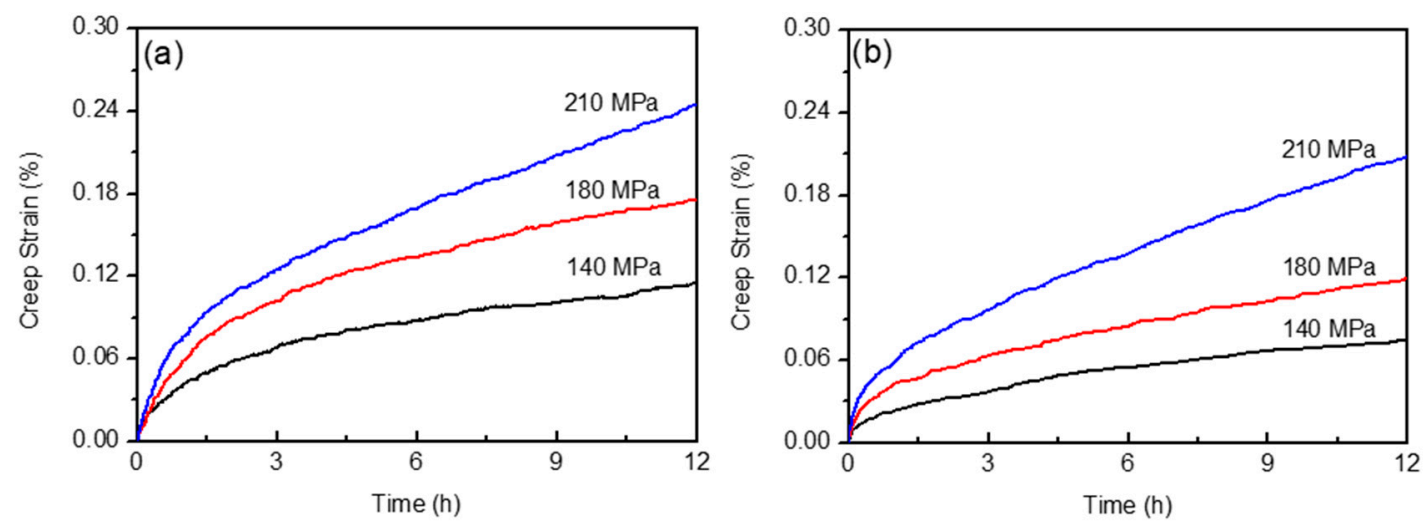

Figure 6. Creep behaviors of the $0 \mathrm{~h}$ - (a) and $12 \mathrm{~h}$ - (b) preaged AA2524 under the applied stress of $140 \mathrm{MPa}, 180 \mathrm{MPa}$, and $210 \mathrm{MPa}$.

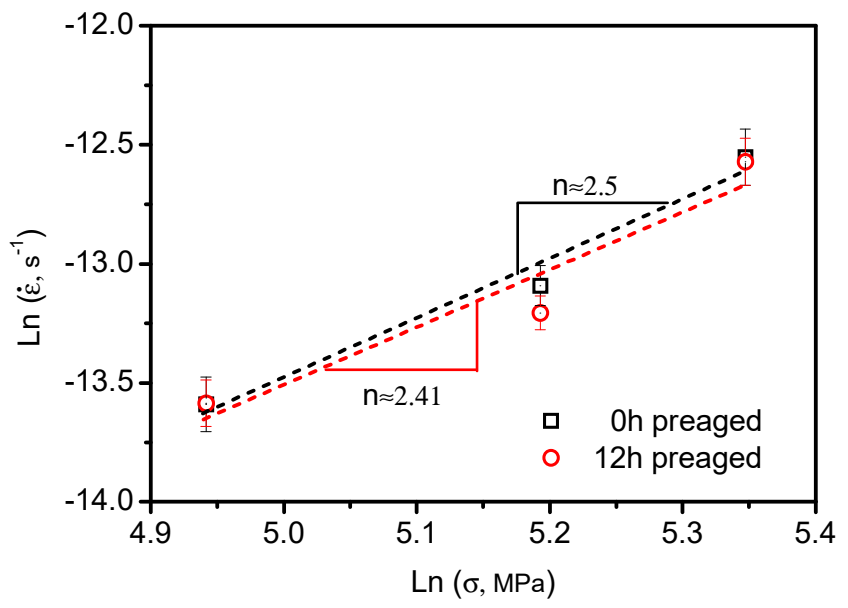

Figure 7. Relationship between $\ln \sigma$ and $\ln \dot{\varepsilon}_{s S}$ of the 0 h- and 12 h-preaged AA2524.

\subsection{Micro-Creep Mechanism}

Based on the aforementioned studies, the steady-state creep of the $\mathrm{Al}$ alloy was mainly dominated by grain boundary sliding and dislocation activities in individual grains and seemed independent of the precipitate size. In order to minimize the effect of grain boundaries and explore the steady-state creep mechanism dominated by precipitate growth, an indentation strain-rate jump test was performed on the as-received $\mathrm{Al}$ and after $3 \mathrm{~h}, 6 \mathrm{~h}$, and $12 \mathrm{~h}$ of pre-aging. As the penetration depth was only $2500 \mathrm{~nm}$, which covered only a few grains, the main creep strain should be mainly accommodated by the plasticity of the grain closest to the indenter, and this would highlight the effect of the dislocations and their interactions on the precipitate. This was shown by the detailed TEM characterization of the indent imprint cross sections of the as-received $\mathrm{Al}$ alloy and of the alloy after $12 \mathrm{~h}$ of pre-aging after unloading. In Figure $8 \mathrm{a}-\mathrm{d}$, the deformation of the $\mathrm{Al}$ alloys under the indenter was highly localized, as evidenced by the high dislocation densities in the grains closest to the indenter. Due to the inhomogeneous stress field generated, shear bands were generated where the stress was concentrated in the grain. Massive dislocation activities, such as dislocation entangles, jogs, dislocation slips, were observed, which suggests a major role of dislocation in the indentation creep mechanism of the $\mathrm{Al}$ alloys under study. 

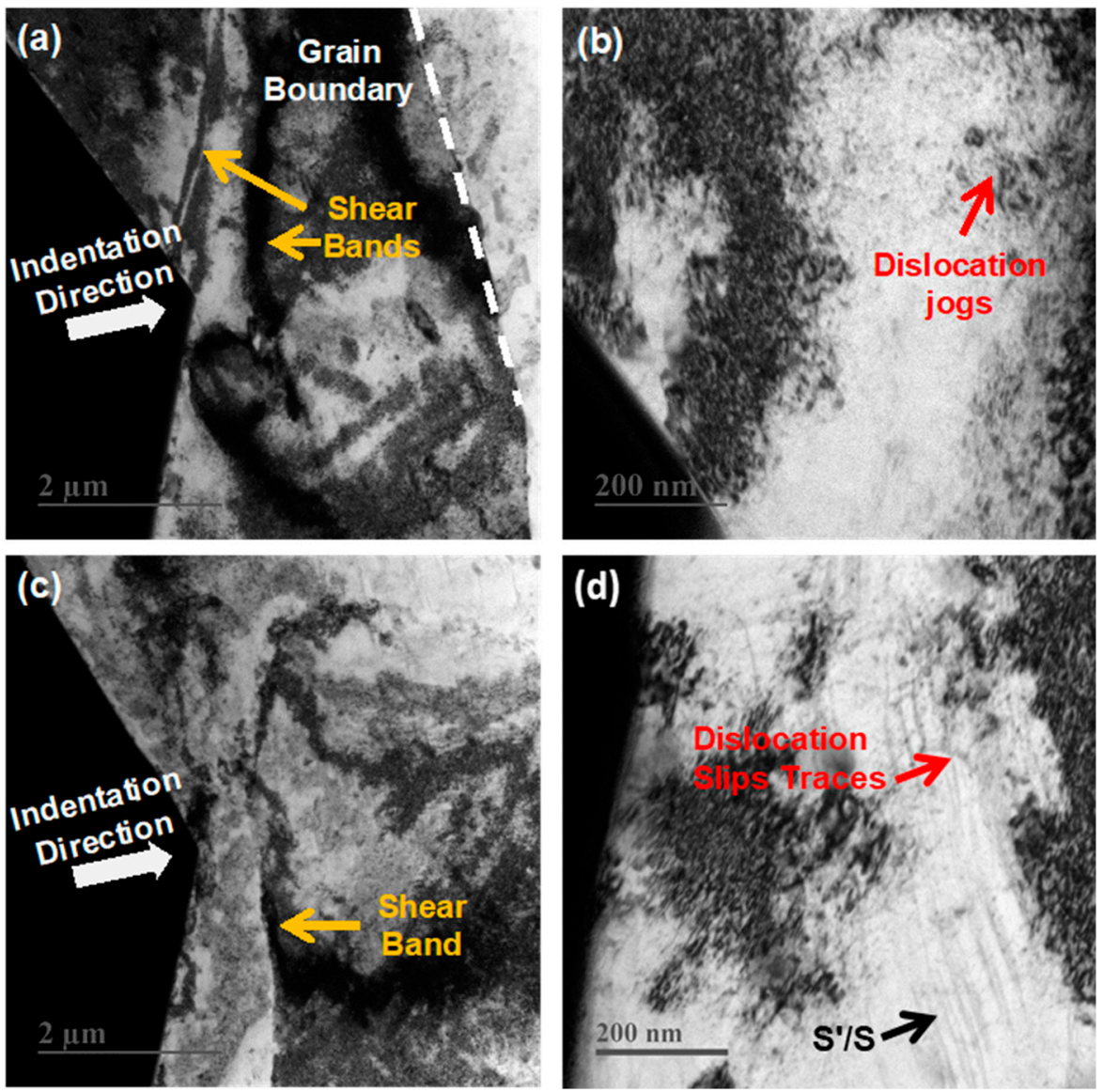

Figure 8. TEM micrographs of lamellae extracted from the indentation imprints of AA2524. (a,b) Pre-aged $0 \mathrm{~h}$ specimen and local magnification; (c,d) Pre-aged $12 \mathrm{~h}$ specimen and local magnification.

Figure 9a plots the indentation hardness versus the indentation depth during indentation strain-rate jumping from $0.05 / \mathrm{s}$ to $0.0005 / \mathrm{s}$, showing variations of the hardness at different strain rates. In agreement with the macro-tensile results (Figure 5a), the micro hardness of the $\mathrm{Al}$ alloy increased as the pre-aging time increased from $0 \mathrm{~h}$ to $12 \mathrm{~h}$, due to the precipitate hardening effect, as shown in Figure $9 \mathrm{~b}$. It is instructive that a higher strain rate generally yielded a stronger response for all alloys, which indicates an apparent time-dependent (creep) property of the $\mathrm{Al}$ alloy at the micro scale.
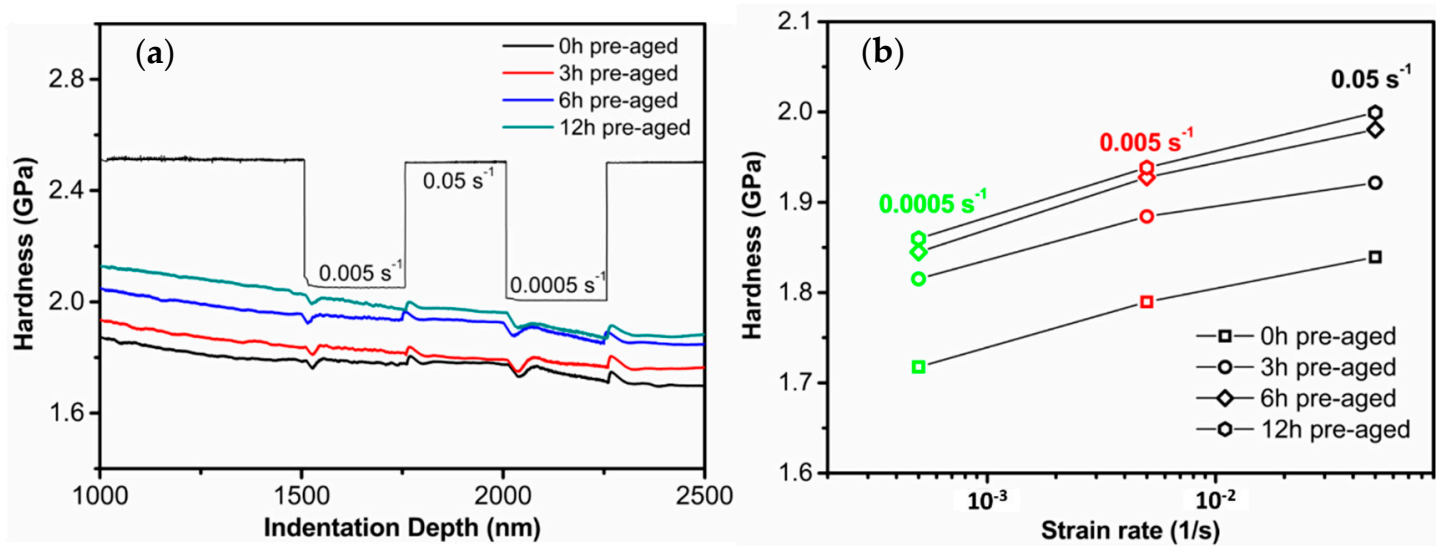

Figure 9. The indentation strain-rate jump experiment of pre-aged AA2524 with three different applied strain rates (a) and the correspondent results for hardness (b). 
Based on the results in Figure 9, the strain rate sensitivity (m [28,29], defined as the logarithmic changes in stress $\sigma$ divided by the strain rate $\dot{\varepsilon}$ of the $\mathrm{Al}$ alloys) could be calculated by:

$$
\mathrm{m}=\frac{\partial \ln \sigma}{\partial \ln \dot{\varepsilon}} \approx \frac{\partial \ln H}{\partial \ln \dot{\varepsilon}}
$$

Table 3 lists the strain rate sensitivities and activation volumes of the $\mathrm{Al}$ alloys with different pre-aging times. Also, the average and standard deviation of $\mathrm{m}(0.0177 \pm 0.0008)$ and $\mathrm{V}^{*}\left(\approx 27.36 \pm 0.64 \mathrm{~b}^{3}\right)$ of four different preaged samples are reported in Table 3. The low standard deviation of the data indicates that the strain rate sensitivities and activation volumes remained almost constant. The experimental results showed that the changes of $\mathrm{m}$ and $\mathrm{V}^{*}$ with nucleation and growth of $\mathrm{S} / \mathrm{S}^{\prime}$ precipitates were not obvious, because the micro-creep mechanism was mainly caused by dislocation interactions (TEM images shown in Figure 8). Within the error tolerance, $\mathrm{m}$ for all alloys was ranged 0.0169-0.0186, in good agreement with that of typical $\mathrm{Al}$ alloys [20,30-32]. This result also correlates well with the similar steady-state creep response of AA2524 alloys (Figure 5b), whose steady state creep rate is insensitive to the aging precipitation process. The strain rate sensitivity values also imply a mechanism dominated by dislocation interactions during micro-creep deformation of the $\mathrm{Al}$ alloys [33]. This explains well the lack of effect of precipitate growth on the indentation creep mechanism and macro steady-state creep mechanism.

Table 3. Strain rate sensitivity $(\mathrm{m})$ and activation volume $\left(\mathrm{V}^{*}\right)$ of the creep aged AA2524 with different pre-aging treatments. $\mathrm{B}$ is the burger's vector of pure $\mathrm{Al}, \approx 0.286 \mathrm{~nm}$.

\begin{tabular}{ccc}
\hline Pre-Aged & $\mathbf{m}$ & $\mathbf{V}^{*}\left(\mathbf{b}^{\mathbf{3}}\right)$ \\
\hline $0 \mathrm{~h}$ & $0.0186 \pm 0.0021$ & $27.50 \pm 0.94$ \\
$3 \mathrm{~h}$ & $0.0182 \pm 0.0009$ & $26.67 \pm 0.52$ \\
$6 \mathrm{~h}$ & $0.0169 \pm 0.0018$ & $28.18 \pm 1.01$ \\
$12 \mathrm{~h}$ & $0.0171 \pm 0.0016$ & $27.08 \pm 0.98$ \\
\hline AVERAGE \pm STDEV & $0.0177 \pm 0.0008$ & $27.36 \pm 0.64$ \\
\hline
\end{tabular}

The activation volume $\left(\mathrm{V}^{*}\right)$, defined as the separation distance between points of dislocation intersection [34], is a direct measure of the deformation mechanism during indentation creep and can be correlated with the strain rate sensitivity by:

$$
\mathrm{V}^{*}=\sqrt{3} \times \mathrm{K}_{\mathrm{B}} \mathrm{T} \times\left(\frac{\partial \ln \dot{\varepsilon}}{\partial \sigma}\right) \approx \frac{3 \sqrt{3} \times \mathrm{K}_{\mathrm{B}} \mathrm{T}}{m \times H}
$$

Here, $\mathrm{K}_{\mathrm{B}}$ is the Boltzmann constant, and $\mathrm{T}$ is the absolute temperature during indentation creep $(\approx 300 \mathrm{~K})$. The calculated $\mathrm{V}^{*}$ for all alloys are also listed in Table 3. They ranged between 26.67 and 28.18, within error tolerance. The values strongly suggest a creep mechanism dominated by dislocation interactions (thermally activated dislocations) that have been found in other Al alloys [21,35], in accordance with the mechanisms implied by the $\mathrm{m}$ values for the $\mathrm{Al}$ alloys.

\section{Conclusions}

(1) A novel methodology combining macro- and micro-creep techniques was employed to study the effect of $\mathrm{S}^{\prime} / \mathrm{S}$ precipitate growth on the creep mechanism of a typical Al-Cu-Mg alloy (AA2524).

(2) High-density $\mathrm{S}^{\prime} / \mathrm{S}$ precipitates were generated in the $\mathrm{Al}$ alloy after pre-aging at $180{ }^{\circ} \mathrm{C}$, and the precipitate size increased approximately linearly to $\approx 32 \mathrm{~nm}, \approx 60 \mathrm{~nm}$, and $\approx 105 \mathrm{~nm}$ after $3 \mathrm{~h}, 6 \mathrm{~h}$, and $12 \mathrm{~h}$ of pre-aging, respectively. Despite this, the grain structure was not altered.

(3) The precipitate growth could strengthen effectively the Al alloy, but the creep behavior was suppressed. The macro-creep tests revealed that the precipitate growth could significantly shorten the primary creep time, mainly due to the precipitates pinning dislocation. However, the steady-state 
creep rate was approximately unchanged. The calculated stress exponent was $2.4-2.5$, implying a macro steady creep mechanism dominated by grain boundary sliding and dislocation slipping.

(4) To eliminate the effect of grain boundaries and to highlight the role of the precipitates, micro strain-rate jump tests were applied. The results suggest a minor role of the $S^{\prime} / S$ precipitates on the creep mechanism of the $\mathrm{Al}$ alloys, since the dominant mechanism was still controlled by dislocations rather than by the aging precipitates.

Author Contributions: Conceptualization, L.Z. and M.H.; Methodology, Y.X. and L.Y.; Formal Analysis, H.Y. and L.Y.; Investigation, Y.X.; Data Curation, Y.X.; Writing-Original Draft Preparation, Y.X. and L.Y.; Writing-Review \& Editing, H.Y. and L.Y.; Supervision, L.Z.

Funding: This work was supported by the National Key R\&D Program of China (2017YFB0306300), the National Natural Science Foundation of China (No. 51905551,51675538,51601060), and the project of State Key Laboratory of High-Performance Complex Manufacturing (Kfkt2018-03, ZZYJKT2019-11).

Conflicts of Interest: The authors declare no conflict of interest.

\section{References}

1. Dursun, T.; Soutis, C. Recent developments in advanced aircraft aluminium alloys. Mater. Des. 2014, 56, 862-871. [CrossRef]

2. $\mathrm{Xu}, \mathrm{Y}$; Zhan, L.; $\mathrm{Xu}, \mathrm{L}$; Huang, M. Experimental research on creep aging behavior of Al-Cu-Mg alloy with tensile and compressive stresses. Mater. Sci. Eng. A 2017, 682, 54-62. [CrossRef]

3. Xu, Y.; Zhan, L.; Li, W. Effect of pre-strain on creep aging behavior of 2524 aluminum alloy. J. Alloys Compd. 2017, 691, 564-571. [CrossRef]

4. Zhan, L.; Lin, J.; A Dean, T. A review of the development of creep age forming: Experimentation, modelling and applications. Int. J. Mach. Tools Manuf. 2011, 51, 1-17. [CrossRef]

5. Ma, Z.; Zhan, L.; Liu, C.; Xu, L.; Xu, Y.; Ma, P.; Li, J. Stress-level-dependency and bimodal precipitation behaviors during creep ageing of Al-Cu alloy: Experiments and modeling. Int. J. Plast. 2018, 110, 183-201. [CrossRef]

6. Xu, Y.; Zhan, L.; Huang, M.; Shen, R.; Ma, Z.; Xu, L.; Wang, K.; Wang, X. Deformation behavior of Al-Cu-Mg alloy during non-isothermal creep age forming process. J. Mater. Process. Technol. 2018, 255, 26-34. [CrossRef]

7. Yang, Y.-L.; Zhan, L.-H.; Li, J. Constitutive modeling and springback simulation for 2524 aluminum alloy in creep age forming. Trans. Nonferrous Met. Soc. China 2015, 25, 3048-3055. [CrossRef]

8. Zhan, L.-H.; Li, Y.-G.; Huang, M.-H. Effects of process parameters on mechanical properties and microstructures of creep aged 2124 aluminum alloy. Trans. Nonferrous Met. Soc. China 2014, 24, 2232-2238. [CrossRef]

9. Xu, Y.; Zhan, L.; Huang, M.; Liu, C.; Wang, X. Anisotropy in creep-ageing behavior of textured Al-Cu-Mg alloy. Int. J. Light. Mater. Manuf. 2018, 1, 40-46. [CrossRef]

10. Zhan, L.; Tan, S.; Yang, Y.; Huang, M.; Shen, W.; Zhao, X. A research on creep age forming of 2524 aluminum alloy: Springback, mechanical properties and microstructures. Adv. Mech. Eng. 2014, 6, 1-8. [CrossRef]

11. Maximov, J.T.; Duncheva, G.V.; Anchev, A.P.; Ichkova, M.D. Modeling of strain hardening and creep behaviour of 2024T3 aluminium alloy at room and high temperatures. Comp. Mater. Sci. 2014, 83, 381-393. [CrossRef]

12. Chen, J.; Chen, Z.; Guo, X.; Deng, Y. Changing distribution and geometry of $\mathrm{S}^{\prime}$ in $\mathrm{Al}-\mathrm{Cu}-\mathrm{Mg}$ single crystals during stress aging by controlling the loading orientation. Mater. Sci. Eng. A 2016, 650, 154-160. [CrossRef]

13. Yang, L.; Wang, C.; Monclús, M.; Lu, L.; Molina-Aldareguía, J.M.; Llorca, J. Influence of temperature on the strain rate sensitivity and deformation mechanisms of nano-twinned Cu. Scr. Mater. 2018, 154, 54-59. [CrossRef]

14. Sun, W.; Jiang, Y.; Sun, G.; Hu, J.; Zhou, T.; Jiang, Z.; Lian, J. Indentation creep behavior and its relation to activation volume and strain rate sensitivity of nanocrystalline Cu. Mater. Sci. Eng. A 2019, 751, 35-41. [CrossRef]

15. Liu, X.; Zhang, Q.; Zhao, X.; Yang, X.; Luo, L. Ambient-temperature indentation creep in ultrafine-grained titanium processed by ECAP. Mater. Sci. Eng. A 2016, 676, 73-79. [CrossRef] 
16. Hong, Y.; Zhou, C.; Zheng, Y.; Zhang, L.; Zheng, J.; Chen, X. Effect of hydrogen and strain rate on indentation creep of austenitic stainless steel. Int. J. Hydrogen Energy 2019, 44, 1253-1262. [CrossRef]

17. Maier, V.; Durst, K.; Mueller, J.; Backes, B.; Happel, H.W.; GeKen, M. Indentation strain-rate jump tests for determining the local strain-rate sensitivity in nanocrystalline $\mathrm{Ni}$ and ultrafine-grained Al. J. Mater. Res. 2011, 26, 1421-1430. [CrossRef]

18. Sambhava, K.; Nautiyal, P.; Jain, J. Model based phenomenological and experimental investigation of indentation creep in pure Mg and AZ61 alloy. Mater. Des. 2016, 105, 142-151. [CrossRef]

19. Wang, C.; Liao, Y.; Chu, J.P.; Hsueh, C. Viscous flow and viscosity measurement of low-temperature imprintable Au-Cu-Si thin film metallic glasses investigated by indentation creep. Mater. Des. 2017, 123, 112-119. [CrossRef]

20. Koch, S.; Abad, M.D.; Renhart, S.; Antrekowitsch, H.; Hosemann, P. A high temperature indentation study of Al-Cu wrought alloy. Mater. Sci. Eng. A 2015, 644, 218-224. [CrossRef]

21. Böhner, A.; Maier, V.; Durst, K.; Höppel, H.W.; Göken, M. Macro- and nanomechanical properties and strain-rate sensitivity of accumulative roll bonded and equal channel angular pressed ultrafine-grained materials. Adv. Eng. Mater. 2011, 13, 251-255. [CrossRef]

22. Lei, C.; Li, H.; Fu, J.; Bian, T.J.; Zheng, G.W. Non-isothermal creep aging behaviors of an Al-Zn-Mg-Cu alloy. Mater. Charact. 2018, 144, 431-439. [CrossRef]

23. Shen, F.; Wang, B.; Liu, H.; Jiang, Y.; Tang, C.; Shou, W.; Pan, S.; Chen, Y.; Yi, D. Effects of secondary particle-induced recrystallization on fatigue crack growth in AA2524/Al-Cu-Mg T3 alloy sheets. J. Alloys Compd. 2016, 685, 571-580. [CrossRef]

24. Xu, Y.; Zhan, L.; Ma, Z.; Huang, M.; Wang, K.; Sun, Z. Effect of heating rate on creep aging behavior of Al-Cu-Mg alloy. Mater. Sci. Eng. A 2017, 688, 488-497. [CrossRef]

25. Lin, Y.; Xia, Y.; Jiang, Y.; Li, L. Precipitation in Al-Cu-Mg alloy during creep exposure. Mater. Sci. Eng. A 2012, 556, 796-800. [CrossRef]

26. Wang, S.; Starink, M.J. Two types of S phase precipitates in Al-Cu-Mg alloys. Acta. Mater. 2007, 55, $933-941$. [CrossRef]

27. Li, Y.; Shi, Z.; Lin, J.; Yang, Y.; Rong, Q.; Huang, B.; Chung, T.; Tsao, C.; Yang, J.; Balint, D.S. A unified constitutive model for asymmetric tension and compression creep-ageing behaviour of naturally aged Al-Cu-Li alloy. Int. J. Plast. 2017, 89, 130-149. [CrossRef]

28. Mohebbi, M.S.; Akbarzadeh, A. Development of equations for strain rate sensitivity of UFG aluminum as a function of strain rate. Int. J. Plast. 2017, 90, 167-176. [CrossRef]

29. Varam, S.; Rajulapati, K.V.; Rao, K.B.S. Strain rate sensitivity studies on bulk nanocrystalline aluminium by indentation. J. Alloys Compd. 2014, 585, 795-799. [CrossRef]

30. Maier, V.; Merle, B.; Göken, M.; Durst, K. An improved long-term indentation creep testing approach for studying the local deformation processes in nanocrystalline metals at room and elevated temperatures. J. Mater. Res. 2013, 28, 1177-1188. [CrossRef]

31. Wheeler, J.M.; Maier, V.; Durst, K.; Goken, M.; Michler, J. Activation parameters for deformation of ultrafine-grained aluminium as determined by indentation strain rate jumps at elevated temperature. Mater. Sci. Eng. A 2013, 585, 108-113. [CrossRef]

32. Chinh, N.Q.; Csanádi, T.; Győri, T.; Valiev, R.Z.; Straumal, B.B.; Kawasaki, M.; Langdon, T.G. Strain rate sensitivity studies in an ultrafine-grained $\mathrm{Al}-30 \mathrm{wt} \% \mathrm{Zn}$ alloy using micro- and indentation. Mater. Sci. Eng. A 2012, 543, 117-120. [CrossRef]

33. Khan, A.S.; Liu, H. Variable strain rate sensitivity in an aluminum alloy: Response and constitutive modeling. Int. J. Plast. 2012, 36, 1-14. [CrossRef]

34. Ma, K.; Wen, H.; Hu, T.; Topping, T.D.; Isheim, D.; Seidman, D.N.; Lavernia, E.J.; Schoenung, J.M. Mechanical behavior and strengthening mechanisms in ultrafine grain precipitation-strengthened aluminum alloy. Acta Mater. 2014, 62, 141-151. [CrossRef]

35. Gianola, D.S.; Warner, D.H.; Molinari, J.F.; Hemker, K.J. Increased strain rate sensitivity due to stress-coupled grain growth in nanocrystalline Al. Scr. Mater. 2006, 55, 649-652. [CrossRef]

(C) 2019 by the authors. Licensee MDPI, Basel, Switzerland. This article is an open access article distributed under the terms and conditions of the Creative Commons Attribution (CC BY) license (http://creativecommons.org/licenses/by/4.0/). 